\title{
Identification of Quality Open Green Space in Blang Padang Areas
}

\author{
Nasrullah Ridwan ${ }^{\mathrm{a}, 1, *}$, Resky Rusnanda ${ }^{\mathrm{b}, 2}$ \\ a Program Studi Arsitektur, Fakultas Teknik, Universitas Syiah Kuala,Kota Banda Aceh \\ ${ }^{b}$ Politeknik Aceh Selatan, Tapaktuan, Aceh Selatan \\ Iayoen88@gmail.com; ${ }^{2}$ official.reskyrusnanda@gmail.com;
}

\begin{abstract}
Article history:

Accepted

Keywords:

Green Open Space

Blangpadang Areas

Urban Planning

The city of Banda Aceh is the capital of Aceh where people work, from work to school. But the more the population increases, the less green open space in the Banda Aceh region and no longer fulfills its function as supporting the ecological, aesthetic, social, cultural and economic quality of the city. The purpose of this study is to find the composition of the proportion and distribution of green open space, especially in the downtown area of Banda Aceh appropriate to produce a concept green arrangement open space in accordance with its function as a support for the ecological quality of the city which is also in accordance with the typology of Banda Aceh.
\end{abstract}

Spatial Planning

RTRW

Copyright (C) 2018 Politeknik Aceh Selatan. All rights reserved.

\section{Introduction}

Urban areas in Indonesia tend to experience the same problem, namely increasing population growth mainly due to the flow of urbanization so that the management of urban space is not well ordered, for example the conversion of the function of green open space into residential lands, trade, services, and industry. In a city, land use consists of built up and open land. More land is being built, while there is less open space and urban forests. The increase in land area is built in line with the increasing number of residents in the city. Open land which is generally a green open space of the city is converted into buildings. Banda Aceh is the capital of Aceh Province with a population of $5,096,248$ people (in 2016) with an area of $61.36 \mathrm{~km} 2$. research shows that the minimum standard green space needed in the city of Banda Aceh is based on an area of 1,840.77 ha consisting of 1,227.2 ha of public green open space and 613.6 ha of private green open space, while based on the oxygen demand of the population, motorized vehicles and livestock needed green space covering an area of 1,605.82 ha in 2011, 1,838.31 ha in 2014 and 2,148.58 ha in 2018. The existing conditions of green open space in the city of Banda Aceh are 1,474.79 ha consisting of 676.27 ha of public green space and 798.52 ha of private green space, so that it does not meet the minimum adequacy standard for green space requirements based on area and oxygen demand [1].

The lack of Green Open Space in Banda Aceh requires attention from the government and the city community. Some impacts of sub-optimization of green open space (city green space does not meet the number and quality requirements) are reducing city comfort: decreasing regional capacity and capacity (increasing pollution, decreasing groundwater availability, increasing temperature, etc.).

The quality of Green Open Spaces in Blang Padang is declining due to several factors such as the lack of regularity of the community in managing merchandise in places that become open spaces for visitors. Many of us find these traders selling at will regardless of the beauty of this green open space. Management of green open space is related to the interests of the community so the government needs to involve the role of the community. The community must have high awareness of the environment by caring for green open spaces in the surrounding environment. 


\section{Study Literature}

\section{A. Definition of Green Open Space}

Space is a container that includes land space, sea space, and air space, including space in the earth as a unified territory, where humans and other living creatures, carry out activities, and maintain their survival [3]. Open space is a planned space because of the need for meeting places and joint activities in the open air. With a joint meeting and relationships between people, there will likely be various activities in the open public space. Actually, open space is just one type of public space [4].

\section{B. Types of Green Open Spaces}

Types of green open spaces consist of public green open spaces and private green open spaces [5]:

1. Public open spaces

Green open space is a green open space that is owned and managed by the regional government that is used for the benefit of the community in general. Which includes public green open spaces, among others: 1) City parks, 2) Public cemetery parks, 3) Green lines along rivers, roads and beaches.

2. Private Open Spaces

Which includes private green open spaces, among others, in the form of gardens or yard houses / buildings owned by the public / private planted with plants.

\section{Function of Green Open Space}

The function of green open space is [6]:

1. The function of ecological bio (physical), which is to guarantee the procurement of green space to be part of air circulation (city lungs), microclimate regulator, so that the air and water circulation system can run smoothly, as a shade, oxygen producer, rain absorber, provider of animal habitat, absorbers (processors) of air, water and soil median pollutants and winds.

2. Socioeconomic (productive) and cultural functions that are able to describe local cultural expressions. Green Open Space is the communication media of the city, recreation areas, places of education and research.

3. Urban ecosystems producing oxygen, flowering, fruiting and beautiful leafy plants and can become part of agriculture, forestry and so on.

4. The aesthetic function is to increase comfort, beautify the city environment both from the micro scale: home page, residential environment, and macro: the overall city landscape. Able to stimulate the creativity and productivity of city residents. It can also be active or passive recreation such as playing, exercising, or other socialization activities that also produce a "balance of physical and psychological life". Can create a harmonious and balanced atmosphere between various buildings, road infrastructure urban forest trees, urban parks, agricultural city parks and forestry building parks, green lane roads, railroad banks and blue lane banks.

\section{Benefits of Green Open Space}

The benefits of open space are [3]: 1) Providing freshness, comfort, and environmental beauty. 2) Provide a clean and healthy environment for city dwellers, and 3) Provides results in the form of wood products, leaves, flowers and fruit. 
According to [7] concerning Guidelines for the Provision and Utilization of Green Open Space in Urban Green Areas, both public and private green open space, has a main (intrinsic) function, namely ecological functions and additional (extrinsic) functions, namely aesthetic functions social and economic functions. In an urban area, these four main functions can be combined according to the needs, interests and sustainability of the city such as water protection, ecological balance and biological conservation.

\section{E. The concept of Green Open Space}

Green Open Space (RTH) of the city is part of open spaces (open spaces) of an urban area filled with plants, plants, and vegetation (endemic, introduction) to support the direct and / or indirect benefits generated by green space in the city that is security, comfort, welfare, and beauty of the urban area. Based on its natural weight, the form of green open space can be classified into (a) natural green open space (wild / natural habitat, protected area) and (b) non-natural open green space or built green open space (urban agriculture, urban gardening, sports field, cemetery, based on nature and the ecological character is classified into (a) the form of regional green space (area, non-linear), and (b) the form of green space (corridor, linear), based on land use or functional area classified into (a) green space commercial area, (b) ) Green space in industrial areas, (c) green space in residential areas, (d) green space in agricultural areas, and (e) green space in special areas, such as cemeteries, defense and security, sports, natural [8].

\section{Method}

The method used in this research is descriptive. Descriptive method is a method in examining a group of people, an object, or a set of conditions where the purpose of this method is to make a description, a systematic, factual, and actual description of the facts investigated (Nazir, Moh. In Resky Rusnanda. 2014 ).

Data collection methods used in this study are the method of observation and study of literature. Observations made by taking primary data and secondary data. Primary data, namely data directly obtained from the first source from the study site, while secondary data obtained from other sources. The data that has been collected is then processed to find out how the quality and comfort in the Blang Padang region.

\section{Results and Discussion}

Blang Padang is an area located in Kampung Baru, Baiturrahman District, Banda Aceh. This place is one of the green open spaces which is one of the destinations of the people of Banda Aceh. Blang Padang region is separated by a road into two areas, namely the West and East areas. The overall area of Blang Padang is around 8 ha.

Blang padang is a vast and expansive field in the middle of banda Aceh city which is close to the north with Baiturrahman Mosque and south to the tsunami museum, korkof [Dutch grave] and east with the afternoon playground [Taman Sari] and the west with Rumah Sick Mother Child, in the field was also planted a duplicate of Ri 1 aircraft grants the people of Aceh for Indonesia in the struggle for independence, and also there is a typical culinary of Aceh in addition to the plane and neatly cut grasses that make a beautiful and comfortable atmosphere to visit.

Blang Padang Field is one of the historical sites in Aceh. Many historical stories have been engraved from this field. It's just that Blang Padang Field is not made directly by human hands, so it feels different from other historical sites in Aceh. 


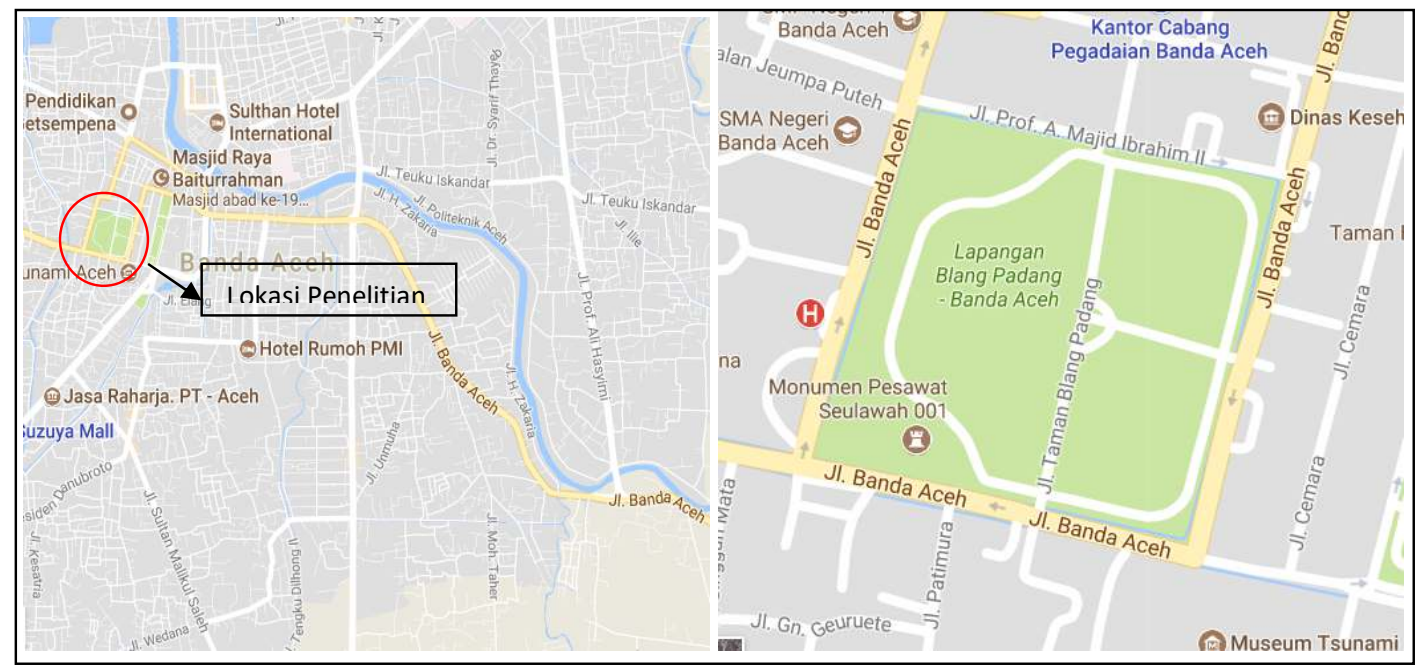

Fig.1 Research Areas

Blang Padang area is surrounded by shady trees and is one of the Green Open Spaces classified as Green Open Space in the City of Banda Aceh.

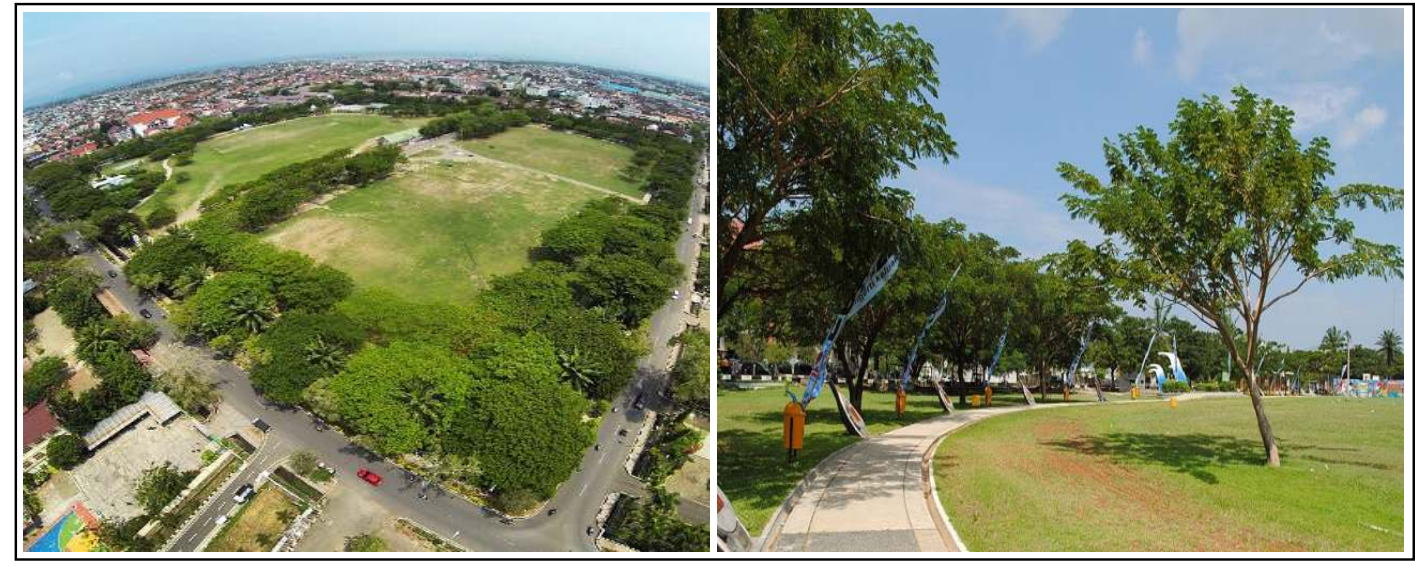

Fig.2. Existing Conditions

On entering the Blang Padang Region we can immediately find the portal on the right and left of the gate that serves as the entrance sign for walkers and runners. But people abusing the functionality of the portal and the pedestrian area in Blang Padang, a place of street vendors and motorcycle parking. People use the area as a pathway of motor vehicles thereby reducing the quality of pedestrian.

In the right-left area of the running or pedestrian path, there are various kinds, food vendors who surround the path. This condition is very disturbing for runners and for pedestrians. Runners / walkers will feel uncomfortable when they walk / run for the buyers who would sit looking at the walkers / runners and also inhibits the activity of walkers and runners because the buyer of food that would also passing across the running track. This happens because there is no parking space provided. People who visit the area bring their own transportation and park their motorcycle in the areas, on the sidewalk outside the road, or on the side of the road. Because of this, the quality and comfort of the area has been disturbed due to the abuse. 

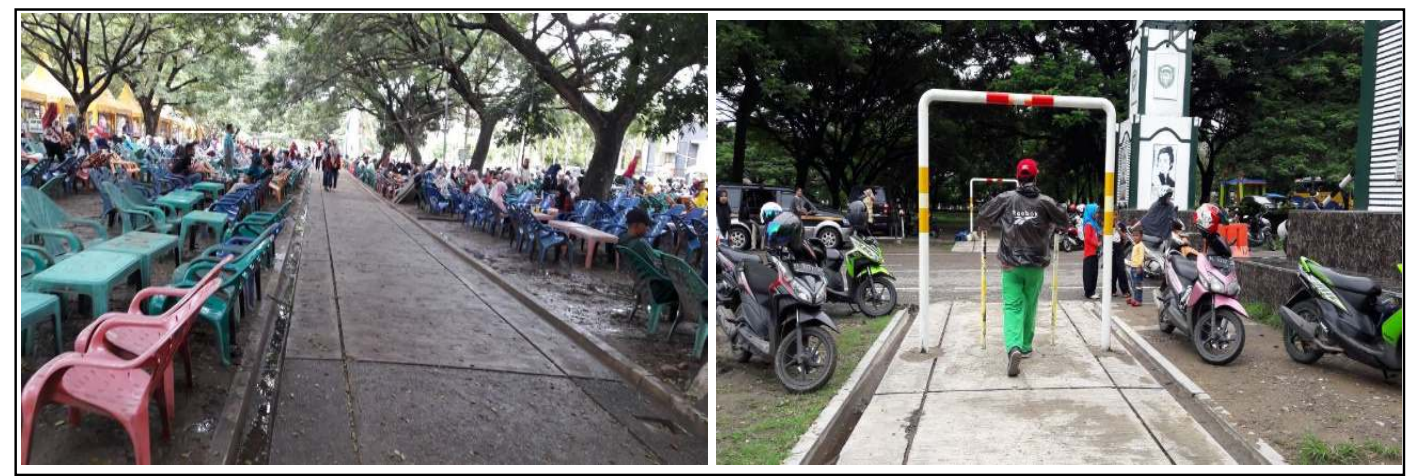

Fig.3. Entrances, places to walk and run

At the time of rain, Blang Padang area that is generally used as a football field flooded by rainwater so that the field cannot be used properly. It was also due to lack of maintenance on the field and the lack of rainwater shelters in the Blang Padang area.

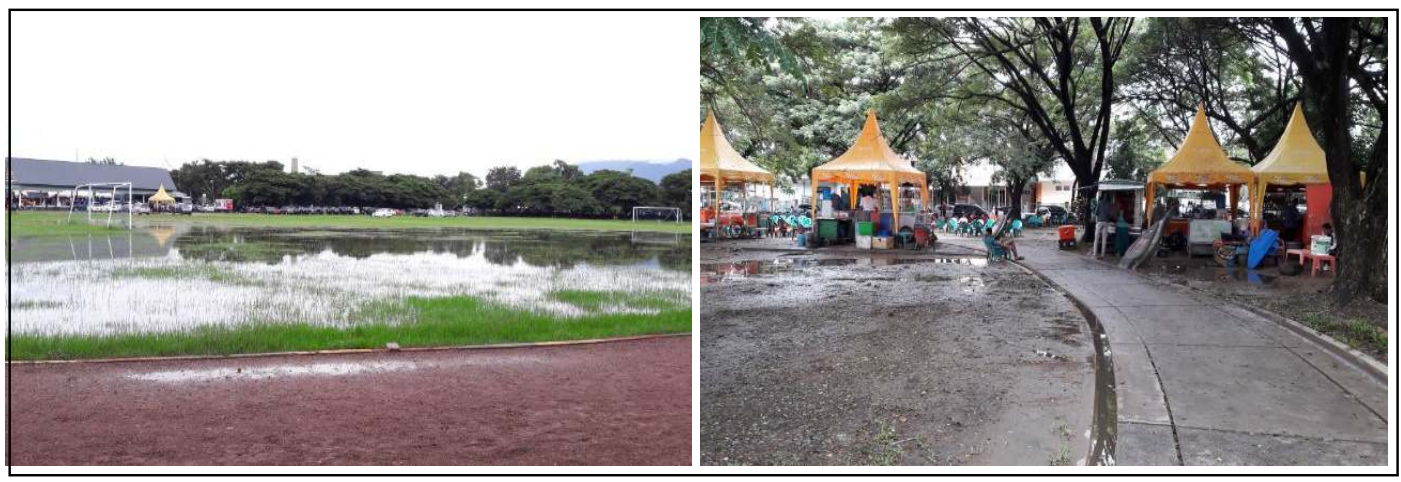

Fig.4. Rainwater flooded area

On one side of the runners/pedestrian pathways there are volleyball and archery facilities surrounded by various vegetation that can provide comfort and shade when the community is in the field.

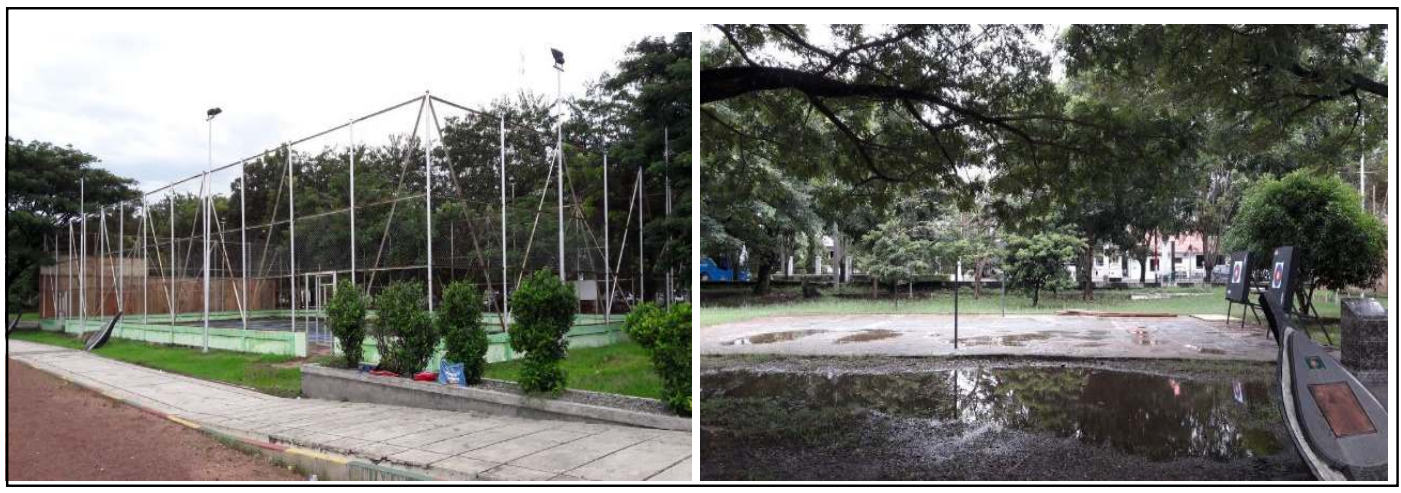

Fig.5. Sport Areas 


\section{Conclusion}

Green Open Space is an area that has an open nature and natural and artificial vegetation. There are various types of green space such as urban parks, urban forests, sports fields, public cemeteries and so forth. Blang Padang Field is a sports field which is one of the Green Open Spaces in Banda Aceh City. Blang Padang areas becomes an important component and functions as a playground is also a sports area. In addition, Blang Padang Field also improves environmental quality and has a major role as a lung or oxygen provider for the city of Banda Aceh. It's just that the quality and comfort of the Blang Padang Field itself is still very lacking due to the lack of public awareness in utilizing / using it properly and properly also in maintaining / caring for the Blang Padang Field.

\section{References}

[1] http://www.jurnal.unsyiah.ac.id/MSDL/article/view/846)

[2] Resky Rusnanda. 2014."Kajian Potensi Kota Tapaktuan, Berbasis Masyarakat Lokal”. Repository USU: Medan.

[3] Permendagri No.1, Tahun 2007 Tentang Penataan Ruang Terbuka Hijau Kawasan perkotaan

[4] Sujarto, Budiharjo. 2005. "Mewujudkan suatu Kota yang Berkelanjutan di perlukan keberadaan penyeimbang dengan penyediaan Ruang Terbuka Hijau". Unikom

[5] UU No.26, Tahun 2007 Tentang Penataan Ruang.

[6] Direktorat Jenderal Penataan Ruang Departement Pekerjaan Umum, 2008

[7] Permen PU No. 5 / PRT / M, 2008

[8] A . Sabdey, dkk. 2017." Kajian Pembangunan Ruang Terbuka Hijau (RTH) Pada Area Tempat Pembuangan Akhir (TPA) Sampah”. Universitas Islam Sultan Agung Semarang. 